\title{
INTEGRASI SISTEM DATA KECELAKAAN LALU LINTAS DI KABUPATEN JEMBER
}

\author{
Kuntoro Bayu Ajie ${ }^{1}$, Harnen Sulistio ${ }^{2}$, Agus Suharyanto ${ }^{3}$ \\ ${ }^{1}$ Mahasiswa Program Magister Jurusan Teknik Sipil Universitas Brawijaya Malang \\ ${ }^{2,3}$ Dosen Jurusan Teknik Sipil Universitas Brawijaya Malang ${ }^{2,3}$ \\ Korespondensi : ewool_nee@yahoo.com
}

\begin{abstract}
The rapid development of technology can help people solve their problems faced every day. One of them is the problem in transportation sector related traffic accident data often occur in Jember. Many agencies and institutions that play a role, making the existing data to be different. Traffic accident report from police and patient report in emergency room from hospital is collected from 2012 to 2014. The result of this research is a good integration traffic accident database system between police and hospital using PostgreSQL, an information system about traffic accident recording with the location can be presented in digital map using Microsoft Visual Basic 6.0, and a recommendations to improve the accuracy of existing traffic accident data.
\end{abstract}

Keywords :Integrasi, sistem database, sistem informasi data kecelakaan lalu lintas.

\section{PENDAHULUAN}

Perkembangan teknologi infomasi yang semakin pesat dapat digunakan manusia dalam memecahkan permasalahan yang dihadapi dalam kehidupan sehari-hari. Salah satunya adalah untuk penanganan data kecelakaan lalu lintas yang sering terjadi di Kabupaten Jember.

Banyaknya instansi dan lembaga yang melakukan pencatatan pada data kecelakaan lalu lintas (kepolisian, rumah sakit, asuransi, dan lain-lain) dan kurangnya koordinasi dari pihak-pihak tersebut, membuat data kecelakaan yang ada menjadi berbeda. Permasalahan ini juga telah disampaikan pada laporan Asian Development Bank (Asian Development Bank, 2005), namun sampai sekarang permasalahan terkait perbedaan data kecelakaan lalu lintas di Indonesia khususnya di Kabupaten Jember masih belum terselesaikan.

Akibat dari perbedaan data kecelakaan tersebut, upaya-upaya yang dilakukan dalam mengurangi terjadinya kecelakaan lalu lintas, masih dianggap kurang. Oleh sebab itu, penanganan data kecelakaan lalu lintas yang ada perlu mendapat perhatian khusus.

Tujuan dari penelitian ini adalah untuk:

(1) Membuat perancangan sistem data kecelakaan lalu lintas yang terintegrasi dengan baik antara pihak kepolisian dan rumah sakit.

(2) Membuat sebuah sistem informasi tentang pencatatan kecelakaan lalu lintas dan dapat disajikan dengan peta digital.

(3) Memberikan rekomendasi yang diberikan untuk meningkatkan akurasi data yang ada.

\section{TINJAUAN PUSTAKA}

Beberapa penelitian terdahulu tentang sistem data kecelakaan lalu lintas telah ditinjau untuk memperkuat penelitian yang akan dilakukan. Diantaranya adalah sebagaimana berikut:

1) Estimasi prevalensi kecelakaan lalu lintas dengan menggunakan metode capture-recapture (Utama, Sayekti Udi; Magetsari, Rahadyan; Pribadi, Vitalis;, 2008). Dengan menggunakan metode tersebut diperoleh hasil cakupan data kecelakaan lalu lintas di rumah sakit lebih besar dibanding dengan kepolisian yang memiliki kelengkapan dan ketersediaan data lebih baik.

2) Optimalisasi peran regident kendaraan dan 
pengemudi dalam aplikasi sistem manajemen keselamatan jalan terpadu (IRSMS) integrated road safety management system (Saktiadi, 2013). Dari penelitian ini diketahui bahwa pihak kepolisian belum memiliki SOP untuk IRSMS dan pada umumnya program tersebut belum diimplementasikan di seluruh kepolisian daerah yang ada. SOP lain yang ada juga tidak menyebutkan kebijakan dan tindakan yang harus dilakukan oleh pihak kepolisian terhadap lokasi rawan kecelakaan, kecuali menerima apa adanya.

3) Pemanfaatan algoritma K-MEANS untuk pemetaan hasil klasterisasi data kecelakaan lalu lintas (Izwari, Lizda dan Ayu, Ervina Gita;, 2015). Salah satu saran yang diajukan pada penelitian ini adalah perlunya integrasi terhadap sistem perekapan kejadian kecelakaan yang telah digunakan secara rutin oleh pihak kepolisian.

\section{METODE PENELITIAN}

Lokasi tempat dilakukannya penelitian adalah Kabupaten Jember, dengan menggunakan data sekunder berupa data kecelakaan lalu lintas yang berasal dari Unit Laka Satuan Lalu Lintas Kepolisian Jember dan data pasien kecelakaan lalu lintas dari instalasi gawat darurat rumah sakit umum di Jember. Adapun bagan alir penelitian ditampilkan pada gambar 1.

Setelah dilakukan pengumpulan data-data sekunder, hal berikutnya yang dilakukan adalah membuat rekapitulasi dari data yang sudah ada dan sekaligus dilakukan verifikasi antara data dari kepolisian dan rumah sakit. Proses verifikasi tersebut dengan menyamakan nama korban kecelakaan lalu lintas dari data laporan kepolisian berdasarkan tanggal pelaporan dengan nama pasien yang ada di laporan pasien kecelakaan lalu lintas dari rumah sakit berdasarkan tanggal dirawat.

Dengan adanya sistem informasi yang dibuat, pihak kepolisian cukup melihat nama-nama pasien kecelakaan yang sudah dimasukkan oleh pihak rumah sakit ke dalam sistem dan melakukan tindak lanjut yang diperlukan seperti melengkapi informasi terkait kecelakaan yang terjadi.

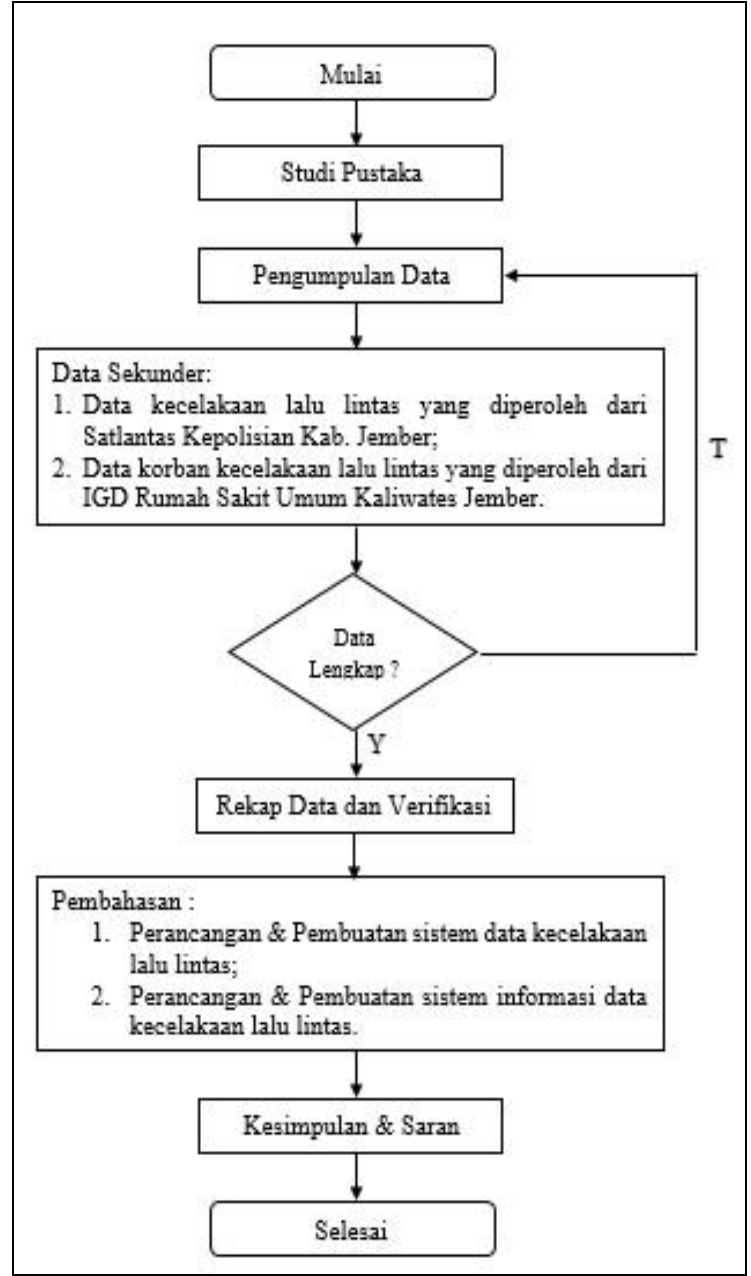

Gambar 1. Bagan alir penelitian

\section{HASIL DAN PEMBAHASAN}

Dari hasil pengumpulan data sekunder dari kedua instansi diperoleh data-data sebagai berikut:

\section{1) Kepolisian}

Data kecelakaan yang diambil meliputi nomor berkas perkara (identitas kecelakaan), tanggal kejadian, tanggal dilaporkan, jam kejadian, lokasi kejadian, koordinat, jenis kecelakaan, kerugian yang ditimbulkan, kondisi cuaca, kondisi permukaan jalan, keterangan tabrak lari, kronogi, nomor polisi kendaraan, jenis kendaraan, merk kendaraan.

2) Rumah Sakit

Data pasien yang diambil meliputi identitas pasien, nama, alamat, umur, jenis kelamin, pekerjaan, tanggal dan jam masuk, kondisi pasien, dan keterangan (biasanya berisikan tentang penyebab pasien dibawa ke rumah sakit seperti kecelakaan lalu lintas di daerah mana, melibatkan apa aja dll.) 


\subsection{Analisa Karakteristik Kecelakaan}

Kecelakaan lalu lintas yang terjadi di Kabupaten Jember dapat diidentifikasi dari data kecelakaan yang diperoleh dan diolah menjadi karakteristik kecelakaan.

1) Karakteristik kecelakaan berdasarkan kendaraan yang terlibat dapat dilihat pada gambar 2

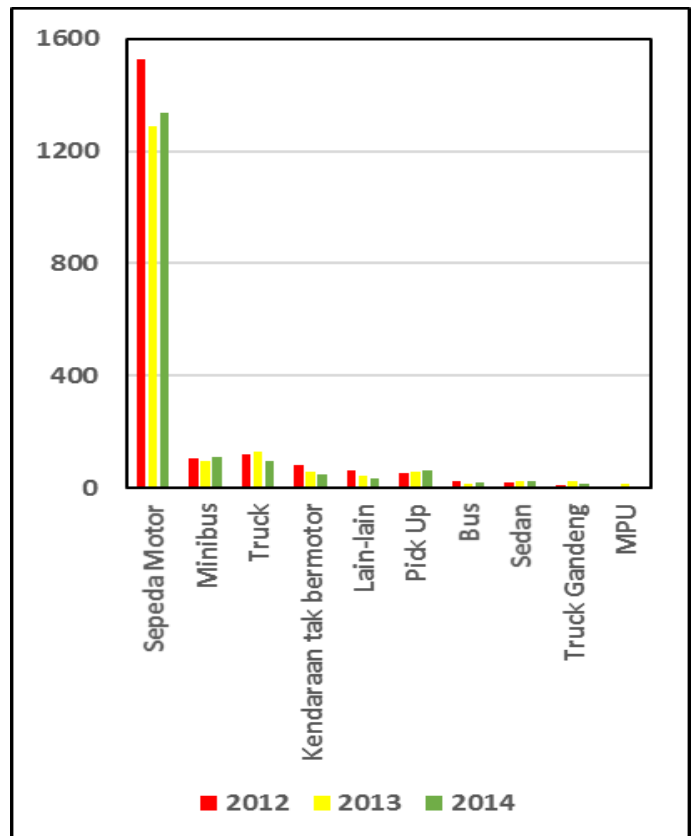

Gambar 2. Kendaraan yang terlibat kecelakaan

Kendaraan yang sering terlibat kecelakaan setiap tahunnya di Kabupaten Jember adalah sepeda motor.

2) Karakteristik kecelakaan berdasarkan tipe tabrakan dapat dilihatpada gambar 3.

Tipe tabrakan yang sering terjadi di Kabupaten Jember adalah tabrak depan dan tabrak samping.

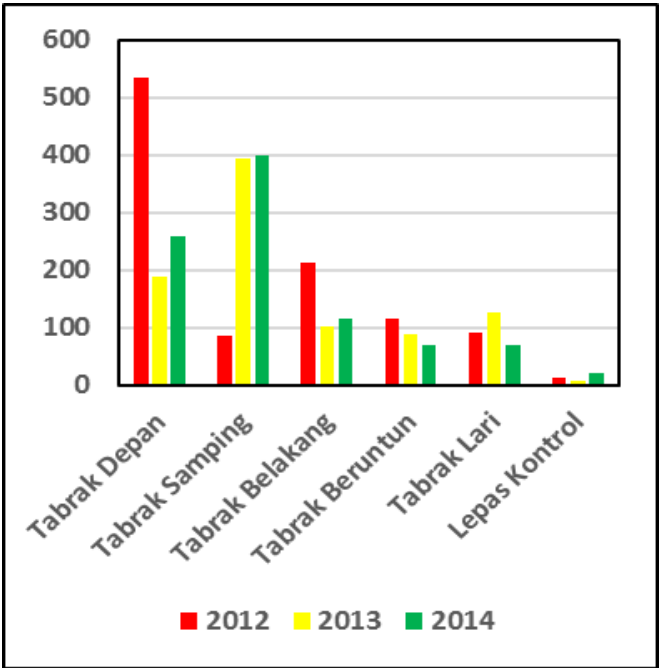

Gambar 3. Tipe tabrakan

3) Karakteristik kecelakaan berdasarkan jenis kelamin pengendara atau pelaku kecelakaan seperti pada gambar 4.

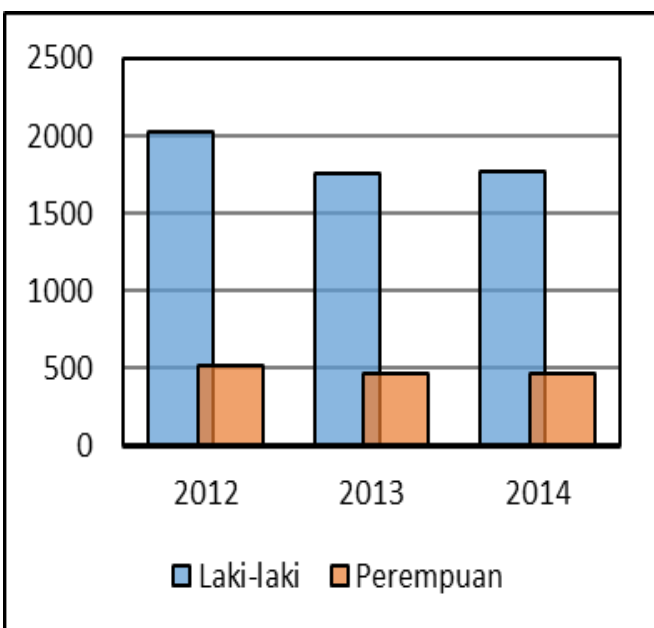

Gambar 4. Jenis kelamin pengendara atau pelaku kecelakaan

Jenis kelamin yang sering terlibat dalam kecelakaan di Kabupaten Jember adalah laki-laki.

4) Karakteristik kecelakaan berdasarkan hari kejadian seperti pada gambar 5. 


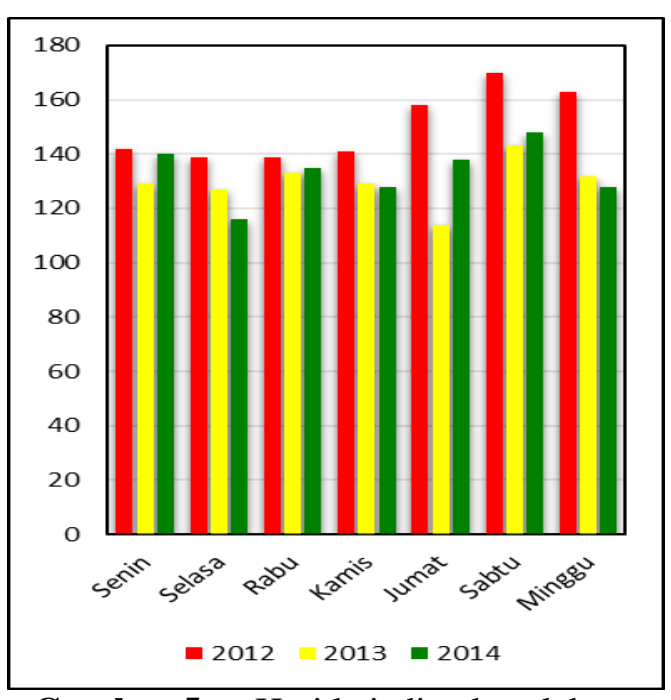

Gambar 5. Hari kejadian kecelakaan

Akhir pekan (hari jumat, sabtu, dan minggu) merupakan hari dimana kecelakaan sering terjadi di Kabupaten Jember.

5) Karakteristik kecelakaan berdasarkan waktu kejadian dapat dilihat pada gambar 6.

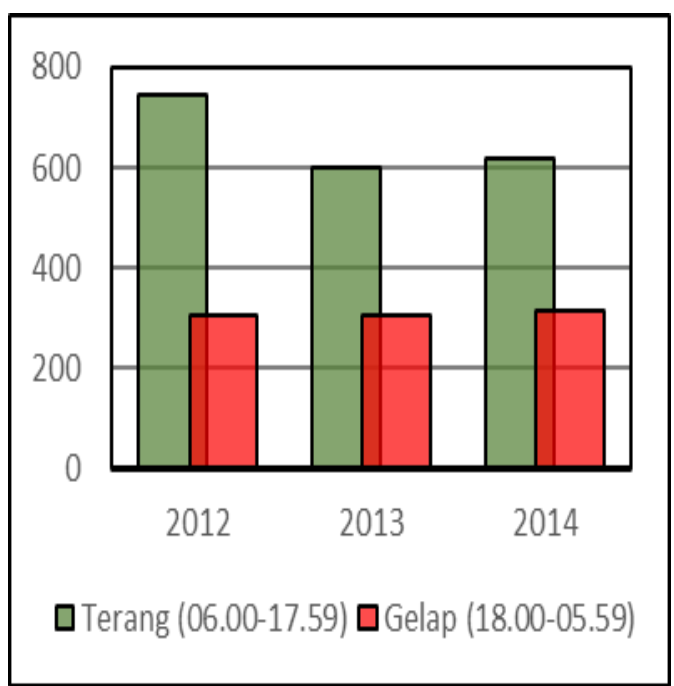

Gambar 6. Waktu kejadian kecelakaan

Waktu kejadian kecelakaan sering terjadi pada waktu terang/ siang hari yaitu pada jam 06.00 sampai dengan 17.59.

6) Karakteristik kecelakaan berdasarkan jenis luka dapat dilihat pada gambar 7.

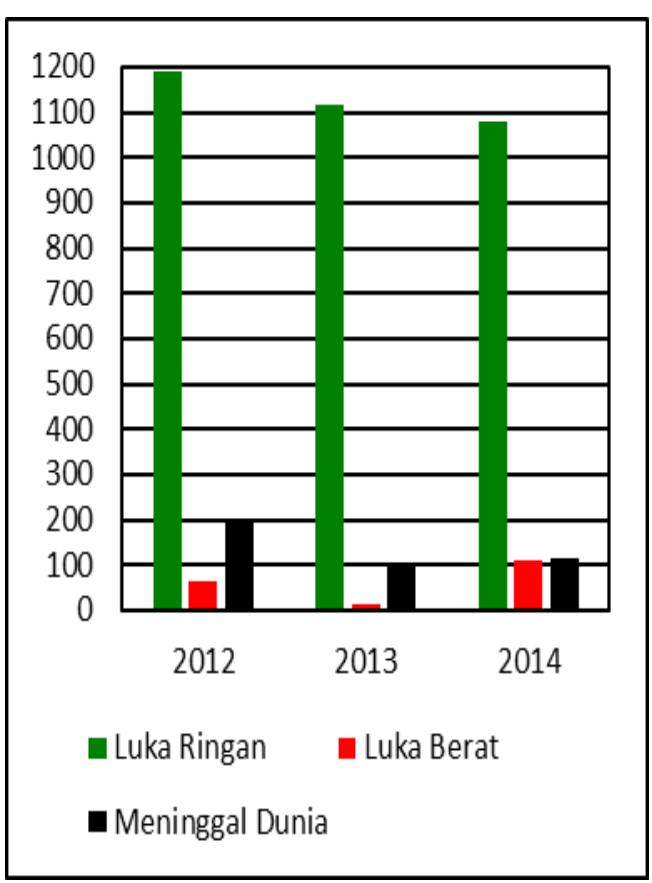

Gambar 7. Jenis luka korban kecelakaan

Terdapat tiga jenis luka akibat kecelakaan yaitu luka ringan, luka berat, dan meninggal dunia. Dari ketiga jenis luka tersebut, luka ringan paling banyak diderita oleh korban kecelakaan lalu lintas.

7) Karakteristik kecelakaan berdasarkan usia pengendara atau pelaku kecelakaan dapat dilihat pada gambar 8 .

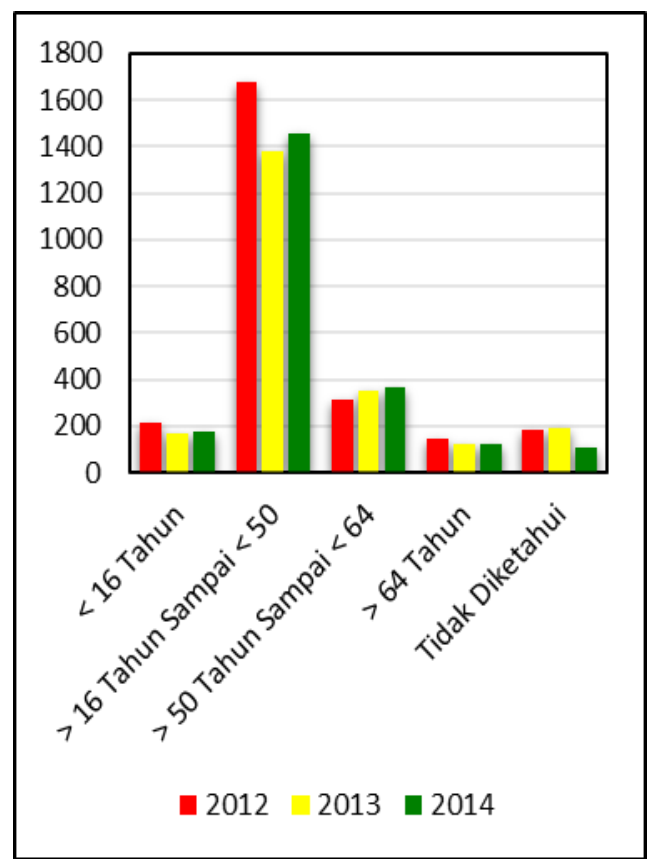

Gambar 8. Usia pengendara atau pelaku kecelakaan 
Kebanyakan dari pengendara atau pelaku kecelakaan berusia sangat produktif yaitu usia lebih dari 16 tahun sampai dengan kurang dari 50 tahun. Hal ini juga memiliki pengaruh terhadap tingkat kemiskinan yang terjadi di Kabupaten Jember.
4.2. Rekapitulasi data kecelakaan dari kepolisian dan rumah sakit

Hasil dari rekapitulasi data dan sinkronisasi data dapat dilihat pada tabel 1. Dari hasil verifikasi yang dilakukan, diketahui bahwa hanya sebagian kecil data pasien rumah sakit yang sama dengan data korban kecelakaan di laporan kepolisian. Hal ini disebabkan karena dari pihak pasien, tidak mau melaporkan kejadian kecelakaan lalu lintas yang dialaminya kepada pihak polisi.

Tabel 1. Hasil rekapitulasi dan verifikasi jumlah korban kecelakaan lalu lintas

\begin{tabular}{c|c|c|c|c|c|c|c|c|c|c}
\hline \multirow{2}{*}{ No. } & \multirow{2}{*}{ Jenis Luka } & \multicolumn{3}{|c|}{ Kepolisian } & \multicolumn{3}{c}{ Rumah Sakit } & \multicolumn{3}{c}{ Hasil Verifikasi } \\
\cline { 3 - 12 } & & $\mathbf{2 0 1 2}$ & $\mathbf{2 0 1 3}$ & $\mathbf{2 0 1 4}$ & $\mathbf{2 0 1 2}$ & $\mathbf{2 0 1 3}$ & $\mathbf{2 0 1 4}$ & $\mathbf{2 0 1 2}$ & $\mathbf{2 0 1 3}$ & $\mathbf{2 0 1 4}$ \\
\hline 1. & Luka Ringan & 1189 & 1116 & 1081 & 159 & 180 & 223 & 1342 & 1312 & 1314 \\
\hline 2. & Luka Berat & 66 & 15 & 109 & 18 & 23 & 12 & 83 & 38 & 121 \\
\hline 3. & Meninggal Dunia & 197 & 107 & 117 & 4 & 4 & - & 199 & 112 & 117 \\
\hline \multicolumn{2}{r}{ Total } & 1452 & 1238 & 1306 & 181 & 207 & 235 & 1624 & 1462 & 1551 \\
\hline
\end{tabular}

\subsection{Desain sistem data kecelakaan lalu lintas di Kabupaten Jember}

Rancangan sistem data dibuat dengan menggunakan aplikasi PostgreSQL dan dapat dilihat pada gambar 9.

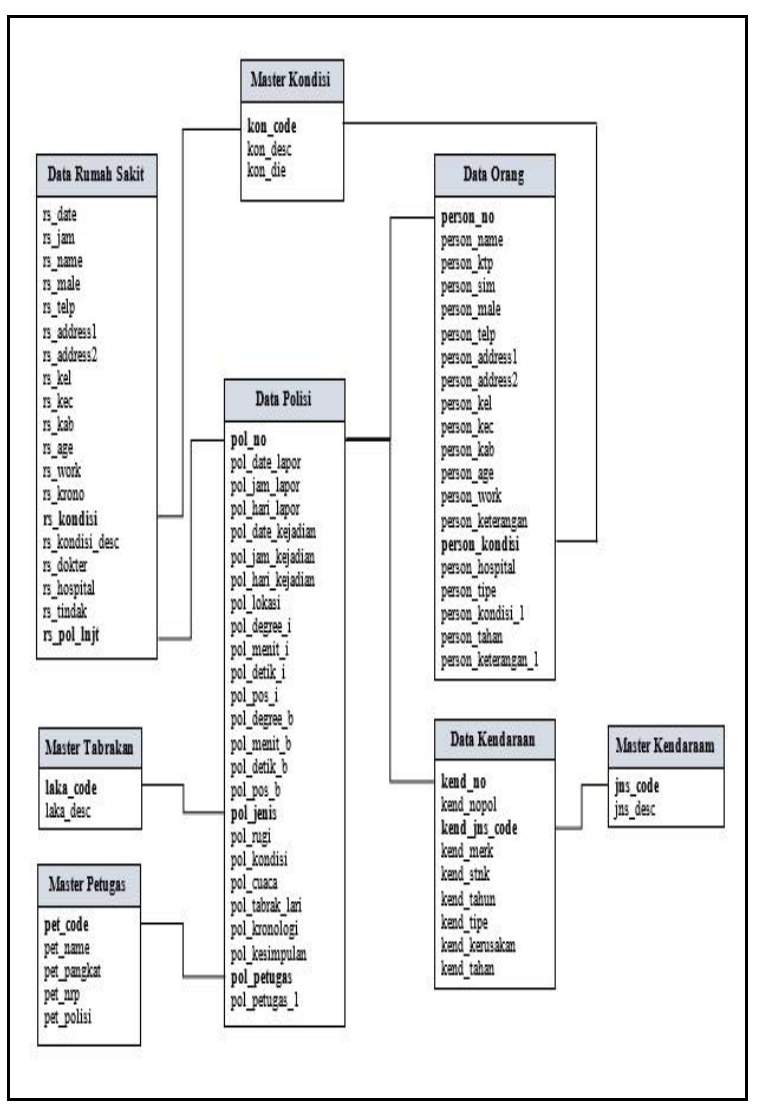

Gambar 9. Rancangan database

Rancangan sistem data yang dibuat dengan menggunakan aplikasi PostgreSQL, terdiri dari 8 tabel utama. Tabel-tabel tersebut adalah:

1) Data polisi

Tabel ini berisikan tentang nomer perkara, tanggal pelaporan, hari pelaporan, jam pelaporan, tanggal kejadian, hari kejadian, lokasi kejadian, koordinat, tipe kecelakaan, kerugian secara materiil, kondisi jalan, kondisi cuaca, keterangan tabrak lari, kronologi kejadian, kesimpulan sementara, petugas yang membuat laporan.

\section{2) Data orang}

Tabel ini mencatat tentang pelaku kecelakaan beserta korban dan saksinya. Adapun yang dicatat dalam tabel ini adalah nama, nomer KTP, nomer SIM, jenis kelamin, nomer telepon, alamat, umur, pekerjaan, jenis luka yang dialami, detail luka, rumah sakit tempat dirawat, sampai dengan keterangan ditahan atau tidak.

3) Data kendaraan

Tabel kendaraan berisi tentang informasi kendaraan yang terlibat dalam kecelakaan. Informasi tersebut meliputi nomor polisi kendaraan, kode kendaraan, merk, nomer stnk, tahun dibuat, kerusakan yang dialami 
akibat kecelakaan, sampai dengan keterangan ditahan atau tidak oleh pihak kepolisian sebagai barang bukti.

4) Data pasien rumah sakit

Tabel ini berisikan tentang data pasien yang dirawat pada rumah sakit/ puskesmas akibat kecelakaan lalu lintas yang dialami. Informasi yang dicatat dalam tabel ini adalah tanggal masuk, jam masuk, nama pasien, alamat, jenis kelamin, umur, pekerjaan, nomer telepon, kronologi kecelakaan, luka yang dialami dan lain-lain.

5) Master kondisi

Tabel ini dibuat untuk mempermudah menentukan kondisi luka yang dialami pasien. Jenis luka yang dialami dibagi menjadi tiga yaitu luka ringan, luka berat, dan meninggal dunia.

6) Master tabrakan

Tabel master tabrakan berisikan informasi tentang tipe-tipe tabrakan yang ada seperti tabrak depan, tabrak samping, tabrak belakang, dan lain-lain

7) Master kendaraan

Tabel master kendaraan berisikan informasi tentang jenis-jenis kendaraan yang terlibat dalam kecelakaan lalu lintas. Bisa merupakan kendaraan bermotor maupun kendaraan tak bermotor.

8) Master petugas

Tabel ini mencatat informasi tentang petugas yang nantinya akan mengoperasikan sistem.

Pembuatan laporan kepolisian tentang kecelakaan lalu lintas, laporan pasien akibat kecelakaan lalu lintas dan peta digital dibuat berdasarkan informasi yang ada pada 8 tabel tersebut.

\subsection{Sistem informasi kecelakaan lalu lintas di Kabupaten Jember}

Setelah sistem data dibuat, langkah berikutnya adalah membuat sistem informasi yang digunakan sebagai sarana untuk memasukkan data kedalam sistem. Sistem informasi kecelakaan lalu lintas di Kabupaten Jember dibuat dengan menggunakan aplikasi Microsoft visual basic 6.0.

Secara garis besar, penggunaan sistem dapat dilihat pada gambar 10.

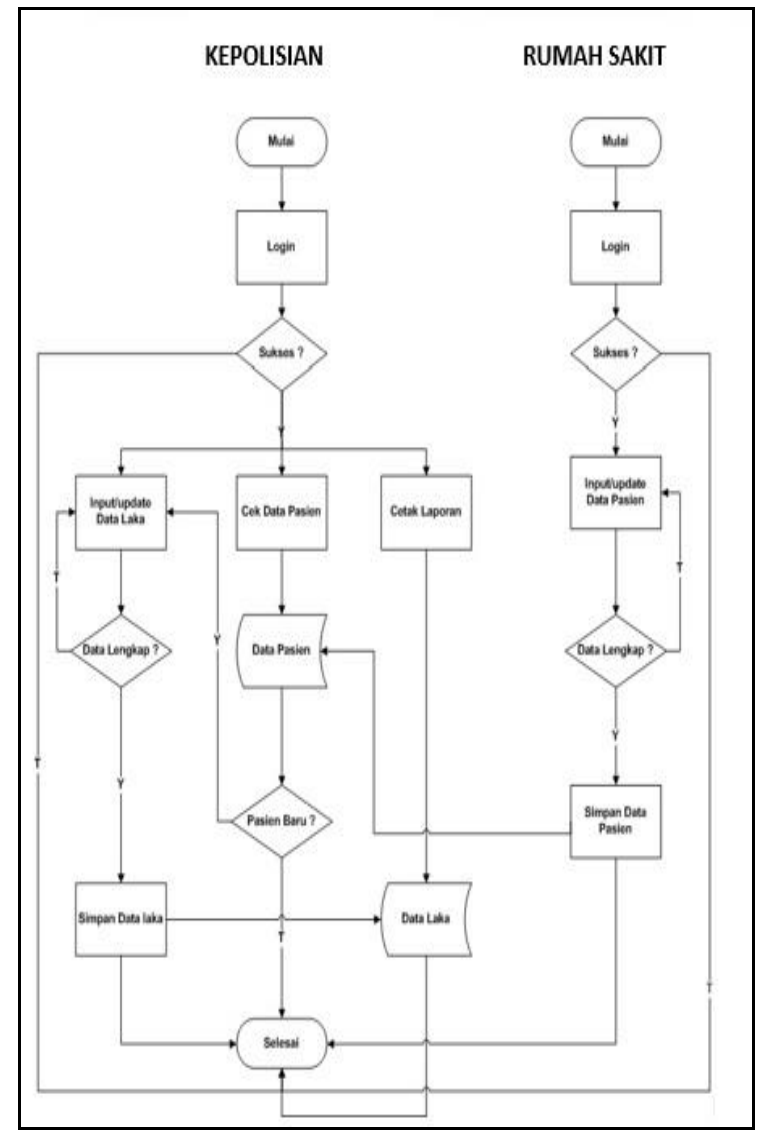

Gambar 10. Flowmap sistem

Hasil keluaran (output) sistem berupa laporan data pasien, laporan kepolisian, dan peta digital dapat dilihat pada gambar 11, gambar 12, dan gambar 13.

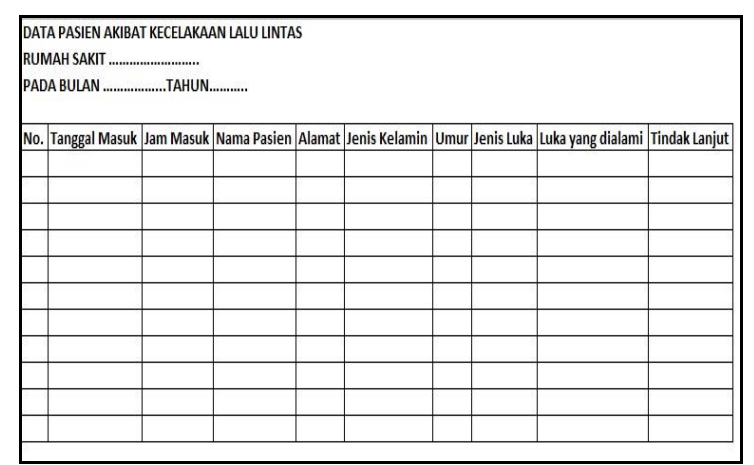

Gambar 11. Laporan data pasien

\section{KESIMPULAN DAN SARAN}

\subsection{Kesimpulan}

Secara umum, hasil penelitian ini ditujukan untuk pihak Kepolisian Republik Indonesia. Berdasarkan rumusan permasalahan yang ada dan hasil dari identifikasi serta pengamatan di lapangan, dapat ditarik kesimpulan sebagai akhir dari penelitian ini yaitu: 


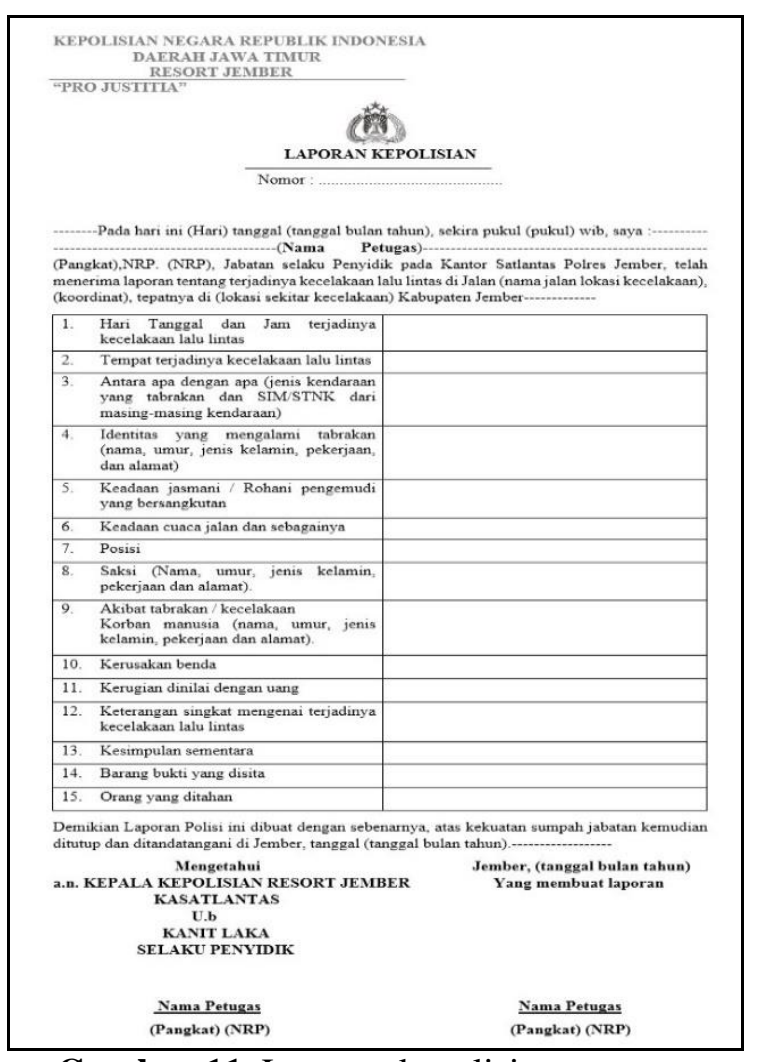

Gambar 11. Laporan kepolisian
1) Telah dibuat sistem data untuk pencatatan kecelakaan lalu lintas di Kabupaten Jember dengan hasil keluaran (output) data pasien rumah sakit menjadi data korban kecelakaan lalu lintas tanpa merubah format.

2) Telah dibuat sistem informasi untuk pencatatan data kecelakaan lalu lintas di Kabupaten Jember yang telah terintegrasi dari instansi yang berbeda dan dapat menampilkan laporan kepolisian, laporan data pasien serta menampilkan lokasi kecelakaan dalam bentuk peta digital.

3) Telah dibuat sistem data untuk pencatatan kecelakaan lalu lintas di Kabupaten Jember dengan hasil keluaran (output) data pasien rumah sakit menjadi data korban kecelakaan lalu lintas tanpa merubah format.

4) Telah dibuat sistem informasi untuk pencatatan data kecelakaan lalu lintas di Kabupaten Jember yang telah terintegrasi dari instansi yang berbeda dan dapat menampilkan laporan kepolisian, laporan data pasien serta menampilkan lokasi kecelakaan dalam bentuk peta digital.

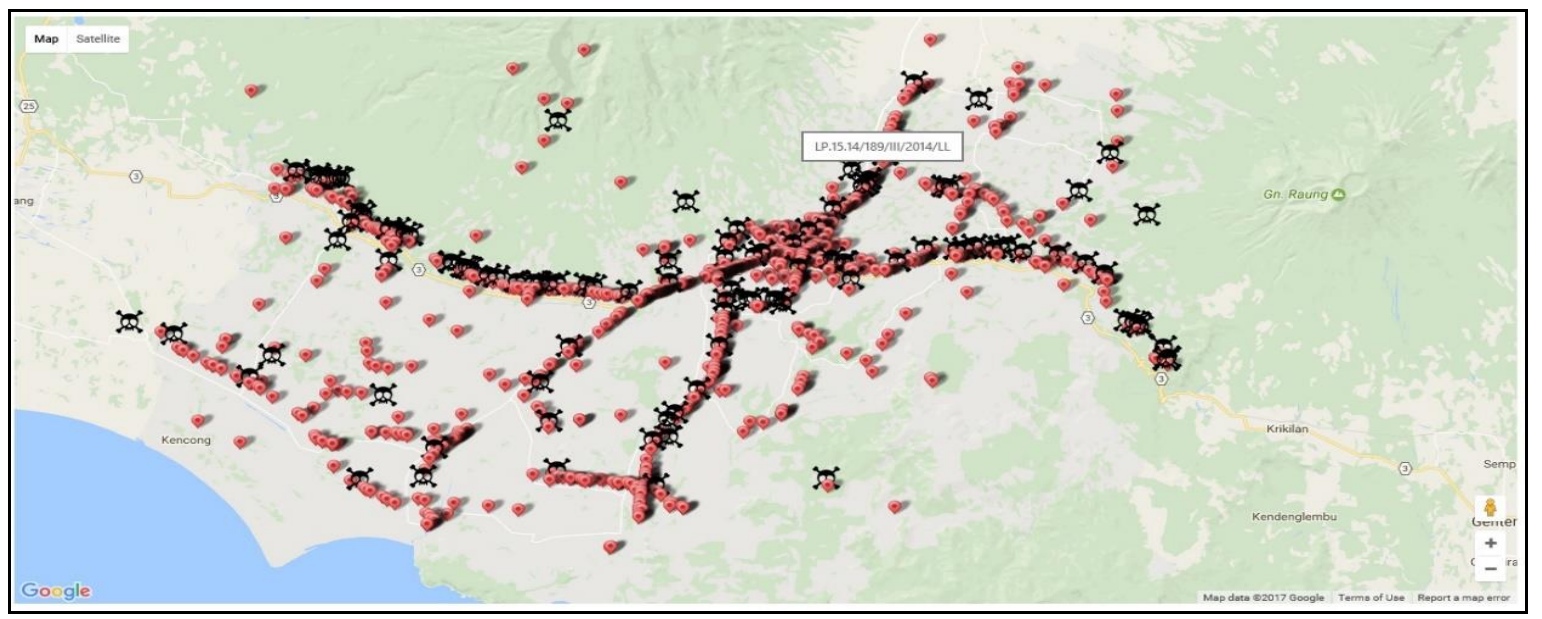

Gambar 11. Peta digital

5) Melihat pentingnya kebutuhan data kecelakaan lalu lintas untuk semua pihak, maka rekomendasi yang diberikan adalah:

a) Perbaikan sistem data kecelakaan lalu lintas di Indonesia hendaknya menjadi salah satu program aksi keselamatan jalan yang harus diperhatikan secara khusus dan segera dilakukan oleh pemerintah Indonesia; b) Standarisasi dalam pelaporan data kecelakaan lalu lintas hendaknya segera dibuat oleh pemerintah;

c) Koordinasi antar pihak dalam melakukan pencatatan data kecelakaan lalu lintas hendaknya perlu ditingkatkan sehingga data kecelakaan lalu lintas menjadi lebih akurat;

d) Data kecelakaan lalu lintas dari berbagai 
instansi yang ada, hendaknya dijadikan sebagai sumber data pelengkap bagi pihak Kepolisian. Mengingat salah satu tugas dari kepolisian adalah melakukan pencatatan dan pelaporan terkait kecelakaan lalu lintas yang terjadi (Anonim, 2009);

e) Hasil dari pencatatan data kecelakaan lalu lintas yang dilakukan oleh pihak kepolisian, hendaknya diumumkan secara keseluruhan dalam situs Kepolisian Republik Indonesia, sehingga masyarakat umum dapat melihat secara langsung;

\subsection{Saran}

Berdasarkan pengamatan di lapangan dan kendala-kendala dalam pelaksanaan penelitian, hasil penelitian ini masih jauh dari sempurna. Mencermati banyaknya persoalan selama penelitian ini dilakukan, maka untuk melengkapi dan menyempurnakan hasil penelitian ini perlu dilakukan penelitian lanjutan dengan saran yaitu:

1) Pengembangan sebuah sistem adalah suatu hal yang wajar dan semakin banyaknya rekomendasi terkait data kecelakaan seperti simulasi kejadian kecelakaan serta banyaknya sistem yang ada, maka perlu adanya pengembangan dari sistem yang sudah dibuat yaitu dengan menggabungkan sistem-sistem yang ada.

2) Perkembangan teknologi yang sangat cepat membuat sistem yang sudah dibuat menjadi ketinggalan, untuk hal ini perlu dikembangkan sistem yang lebih sesuai dengan perkembangan teknologi yang ada.
3) Semakin banyak instansi yang membantu melaporkan data kecelakaan lalu lintas yang terjadi, membuat data kecelakaan lalu lintas yang ada akan menjadi semakin akurat. Oleh sebab itu dalam penelitian selanjutnya, hendaknya melibatkan instansi yang lebih banyak dari penelitian ini.

\section{DAFTAR PUSTAKA}

[1] Anonim. (2009). Undang Undang Republik Indonesia Nomor 22 Tahun 2009 Tentang Lalu Lintas dan Angkutan Jalan. Jakarta: Sekretariat Negara Republik Indonesia.

[2] Asian Development Bank. (2005). ADB-ASEAN Regional Road Safety Program Country Report : CR 3. Manila: Asian Development Bank.

[3] Izwari, Lizda dan Ayu, Ervina Gita;. (2015). Pemanfaatan Algoritma K-Means Untuk Pemetaan Hasil Klasterisasi Data Kecelakaan Lalu Lintas. Jurnal Teknoin, $1-11$.

[4] Saktiadi, I. (2013). Optimalisasi peran regident kendaraan dan pengemudi dalam aplikasi sistem manajemen keselamatan jalan terpadu (IRSMS) integrated road safety management system. Yogyakarta: UGM.

[5] Soehodho, S. (2009). ROAD ACCIDENTS IN INDONESIA. IATSS Research, 6-127.

[6] Utama, Sayekti Udi; Magetsari, Rahadyan; Pribadi, Vitalis;. (2008). Estimasi Prevalensi Kecelakaan Lalu Lintas Dengan Metode Capture-Recapture. Berita Kedokteran Masyarakat, 16-26.

[7] WHO, W. H. (2015). Global Status Report On Road Safety. Italy: World Health Organization. 